\title{
COMPARATIVE STUDY ON TRAUMATIC RETICULOPERITONITIS AND TRAUMATIC PERICARDITIS IN CATTLE AND BUFFALO
}

\author{
Shimaa Fawzy ${ }^{1}$, Naglaa A. Gomaa ${ }^{2}$, Medhat N. Nassif ${ }^{2}$, Ahmed M. Hafez $z^{2}$ \\ ${ }^{1}$ Directorate of Veterinary Medicine, Kaferelsheikh Governorate \\ ${ }^{2}$ Department of Animal Medicine, Faculty of Veterinary Medicine, Kaferelshiekh University
}

\begin{abstract}
This study was carried out to make a comparative clinicopathological, radiographic, and ultrasonographic findings in different forms of TRP \& TP in cows and buffalo. Moreover, to verify the response of both animal species to foreign body syndrome. The present investigation was carried out on 60 animals (diseased buffalo $n=22$, diseased cow $n=18$, healthy cow $n=10$, healthy buffalo $n=10$ ). The diseased animals were allocated into 5 groups based on clinical signs and duration of illness. Full case history was obtained and all animals were subjected to thorough clinical examination. Blood samples were obtained for hematological and biochemical analysis. Radiographic and ultrasonographic examination of reticulum and the cardiac area was performed. The hematological analysis showed a significant decrease in RBCs count, Hb concentration and PCV\% with leukocytosis in all diseased groups. The blood serum biochemical analysis revealed a significant increase in total proteins with a significant increase in globulin and a significant decrease in the albumin concentration in chronic TRP affected cows and buffalo. Haptoglobin was significantly increased in acute TRP buffalo and TP in both cattle and buffalo while IgG was significantly decreased in acute TRP buffalo but increased in chronic conditions. However, cardiac troponin-I concentration increased only in TP affected animals. Finally, it could
\end{abstract}


be concluded that changes in serum protein pattern are an important tool for differentiation between acute and chronic TRP. Cardiac troponin-I is an indicator of TP in cattle and buffalo. Ultrasonography has been suggested as a reliable tool and a method of choice for imaging and evaluating the severity of Traumatic pericarditis. There were non-significant biochemical changes between cattle and buffalo in response to the foreign body syndrome.

Keywords: Traumatic reticuloperitonitis, Traumatic pericarditis, biochemical analysis, ultrasonography, cattle, buffalo

\section{INTRODUCTION}

Traumatic reticuloperitonitis (TRP) is an important and relatively common sporadic gastrointestinal disease of adult dairy cows and buffalo (Abdelaal et al., 2009 and Ghanem, 2010).The importance of the disease is not only due to its higher prevalence among other digestive disorders, but also, due to the difficulty in early diagnosis and evaluation of its sequelae by physical examination especially in buffaloes. In addition, the risk of TRP and its sequelae is considerably higher in buffalo than in cattle (Misk and Semieka, 2001). Therefore, additional diagnostic techniques like ultrasonography are often helpful (Braun et al., 1993).

Generally, the clinical signs of traumatic reticuloperitonitis are variable depends on the severity, duration, and involvement of other organs (Abdelaal., 2009). Pain reaction including stiff gait, arching of the back, and painful urination and defecation are common signs of early TRP in cattle while these signs were less common in buffalo (Saleh et al., 2008\&Radostits et al., 2010). Therefore, an early diagnosis and discriminate between different types of TRP is more difficult in buffalo than in cattle (Misk and Semieka, 2001). 
Laboratory analysis of acute phase proteins (APPs) such as serum haptoglobin is required for early diagnosis and determination of the stage, complication, and prognosis of the diseases (Bozukluhan and Gokce, 2007).Studies of Dubensky \&White (1983) and Jafarzadeh et al.(2004) showed that, the evaluation of total plasma protein is useful for differentiating TRP from other gastrointestinal disorders in cattle. In cattle, cardiac troponin determination may be of value in determining the degree of heart damage in cows with traumatic reticuloperitonitis (Gunes et al.,2008).

Radiography is the best method for detection of metallic foreign bodies in and out the reticulum and determination its position and if it is perforated or not (Khalphallah et al., 2016). Ultrasonography is also considered a useful tool for early detection of TRP and to discriminate between different sequelae which have the same clinical findings. The major advantage of ultrasonography is being able to visualize and assess reticular motility and pericardial effusion (Braun, 2009).

The aim of present study was to conduct a comparative pathological, ultrasonographic, and radiographic findings in different forms of TRP \& TP in cow and buffalo. Moreover, to verify the response of both animal species to foreign boy syndrome.

\section{MATERIAL AND METHODS}

\section{Animals:}

A total of 60 animals were included in this study, of all, 20 healthy animals were used as a control (buffalo, $n=10$; cow $n=10$ ). Diseased buffalo $(n=22)$ and cows $(n=18)$. They were divided into 5 groups according to history, clinical signs, duration of illness as well as

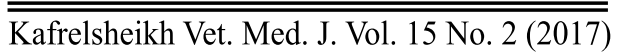


radiographic and ultrasonographic findings of each species. The affected animals were classified into chronic TRP (13 cows and 12 buffalo), acute TRP (5 buffalo) and TP (5 cows and 5 buffalo). The control group of cows belonged to the educational farm animals of Faculty of Veterinary Medicine, Kafrelshiekh University, while the control group of buffalo belonged to the animal production research institute, Mehlet Moussa Experimental Station, Kafrelshiekh governorate. The diseased cows and buffalo (36 females and 4 males) were referred to animal hospital of Faculty of Veterinary Medicine in the period between 2012-2015 and have been diagnosed clinically, radiographically, and ultrasonically to have foreign body syndrome.

\section{Clinical Examination:}

The case history was obtained then a thorough clinical examination of all animals was carried out according to Rosenberger et al.(1979) and Radostits et al.(2010).

\section{Radiographic Examination:}

Lateral radiography of the caudal thorax and cranial abdomen was performed using Fischer imaging system RMX-625R (manufactured by Fisher imaging company, USA). An x-ray machine with a maximum capacity of $150 \mathrm{kVp}$ and $1250 \mathrm{mAs}$ was used in our study. Radiographic examination was used to detect the position foreign body in reticulum and its sequelae, along with the status of the diaphragm and cardiac area.

\section{Ultrasonographic Examination:}

The ultrasonographic examination of reticulum and heart was carried out using a 3.5- $5 \mathrm{MHZ}$ convex transducer on standing position. The reticulum was examined in the cranioventral abdomen caudal to the 
xiphoid cartridge while the heart was examined from right and left parasternal region up to the level of the elbows between the $3^{\text {rd }}$ and $6^{\text {th }}$ intercostal spaces as described by Braun and Goetz (1994).

\section{Hematological and Biochemical analysis:}

From each animal, two blood samples were obtained. One blood sample was taken on a heparinized test tube for hematological examination. Another blood sample was taken on a plain tube to yield serum which separated by centrifugation $3000 \mathrm{r} / \mathrm{m}$ for 10 minutes and kept frozen at $-20 \mathrm{c}^{\circ}$ until analyzed. Serological biochemical examination was performed using spectrophotometer (Turner 690, USA) to determine serum concentration of total protein, albumin, IgG according to methods were described by Cannon (1974), Bartholomew and Delaney (1966), and Shan et al.(2000), respectively. Serum globulin concentration was determined by subtraction of albumin from total protein and then calculate $\mathrm{A} / \mathrm{G}$ ratio. Haptoglobulin and Cardiac Troponin-I concentration were determined using a commercially available ELISA kits (Haptoglobulin test kitsand Troponin-T-hs-Cal-Set kits)used for human medicine, using Cobas e 411 analyzer, Germany.

\section{Statistical analysis:}

Data were analyzed using a statistical software package (SPSS for Windows, Version 16.0 Chicago, SPSS Inc.). All the data are presented as means \pm standard deviations (SD). Student t-test was used for comparison of measured parameters with control groups and between diseased group within the two species. Significant differences were considered at $\mathrm{p}<0.05$. 


\section{RESULTS}

The clinical examination revealed an elevation in rectal temperature which ranged from $\left(39-41 C^{\circ}\right)$. The ruminal contraction was weak or even complete stasis. Heart rate was increased in both TRP and TP diseased groups with cardiac murmurs as muffled heart sound in some cases. Engorgement and pulsation of the jugular vein, edema in brisket or dewlap were observed and these are the characteristic signs in TP groups. By applying the pain test, the affected animal especially cows showed pain reaction which can be detected by grunting.

\section{Hematological Examination:}

There was a significant decrease in RBCs count, $\mathrm{Hb}$ concentration and PCV\% in all diseased animals. In contrast, total leukocyte count was significantly increased in all diseased animals except TP in buffalo (Table. 1\& 2). In chronic TRP, there were significant differences between cows and buffalo in $\mathrm{Hb}$ concentration and leukocytic count. In which cows had a lower $\mathrm{Hb}$ concentration than diseased buffalo while buffalo had a higher leukocytic count than in diseased cows. However, in TP groups, cows and buffalo did not show any significant difference in hematological parameters.

\section{Blood Serum Biochemical analysis:}

The results were summarized in tables 3 and 4.The results revealed a significant increase in total proteins with a significant increase in globulin and a significant decrease in the albumin concentration in both chronic TRP diseased cows and buffalo. In addition, a significant increase in haptoglobin and IgG in only chronic TRP diseased cows was conducted. However, in acute TRP diseased buffalo, there was a significant increase in haptoglobin and a significant decrease in IgG. On 
the other hand, there was a non-significant difference in serum protein pattern between cows and buffalo with chronic TRP. Cardiac troponin-I concentration was significantly increased in TP diseased cows and buffalo. Additionally, there was a significant decrease in $\mathrm{A} / \mathrm{G}$ ratio accompanied by a significant decrease in albumin in TP diseased cows more than buffalo.

\section{Radiographic findings:}

Lateral radiograph of the caudal thorax and cranial abdomen was showing a metallic foreign body in the reticulum of both cows and buffalo (Fig. 1). In acute TRP in buffalo, the reticulum appeared free and clear diaphragmatic line as well as normal size and shape of the heart. In chronic TRP in both cattle and buffalo, thick radiodense adhesion was visualized which may obscure the foreign body from view in some cases. Traumatic pericarditis was diagnosed when foreign bodies were visualized perforating the cranial reticular wall and diaphragm.

\section{Ultrasonographic findings:}

Acute TRP in buffalo appeared as thick and corrugated reticular serosa. Peritoneal effusion appeared as an accumulation of echogenic fibrinous deposits (Fig.2). In contrast, chronic TRP in cattle and buffalo appeared as a thick reticular wall with adhesion to peritoneal wall. The reticular motility disappeared. In some cases with signs of chronic traumatic reticulitis, an abscess in the reticular wall appears as a circumscribed structure containing hypoechoic fluid and deposits of fibrin with various echogenicities (Fig. 3). However, the ultrasonographic appearance of traumatic pericarditisappeared as a large amount of hypoechogenic to echogenic pericardial fluid, and echogenic deposits and strands of fibrin may be seen on the epicardium (Fig. 4). 


\section{DISCUSSION}

The symptoms of foreign body syndrome were varied depending on the site of the reticular perforation and lesion caused by the foreign body (Abdelaal, 2009). In our study, the most common clinical sign in TRP diseased cows and buffalo was a decrease in ruminal contraction or even complete stasis. In addition, mild to moderate elevation in rectal temperature was recorded. These clinical signs are constant with these reported for TRP by others as (Braun et al., 1993, Abdelaal et al., 2009, Radostits et al., 2010). However, the most common signs in TP diseased groups were engorgement of the jugular vein, edema in dewlap or brisket with characteristic muffled or tinkling sound by auscultation on the cardiac area. Engorgement of jugular vein is attributed to the pericardial effusion, increase the intra-cardiac pressure that constrains the cardiac output and impedes the venous return to the heart while increasing venous hydrostatic pressure causes ventral edema and congestive heart failure in the terminal stages (Braun, 2009).

Radiography is a confirmatory tool for diagnosis of TRP in cattle and buffalo when the metallic foreign bodies are visualized beyond the border of the reticular wall. However, radiography failed to identify the inflammatory changes in the reticular wall and pericardial effusion in TP. There were no specific changes in radiographic images between cattle and buffalo.

Ultrasonography should be used simultaneously with radiography. These results agreed with other previous studies (Braun et al. 1994 and Khalaphallah et al., 2016). 
Hematological analysis revealed that there was a significant decrease in RBCs count, $\mathrm{Hb}$ concentration and PCV\% in all diseased groups. This reduction in erythrocytic count and $\mathrm{Hb}$ concentration may be due nutritional deficiency resulting from anorexia occurring during the course of disease or from impaired digestion and accumulation of food material in static rumen as well as may be due to hemorrhage that occur during the perforation of the foreign body to the reticular wall (Roussell et al., 1997, Radostits et al., 2010, Vanitha et al., 2010 and Dodia et al., 2014). Hematocrit value (PCV\%) was significantly decreased in chronic TRP diseased cows and buffalo as well as TP diseased buffalo. This result came in conjugation with a decrease in $\mathrm{RBCs}$ and $\mathrm{Hb}$ concentration and agree with Kumar and Dhar (2013). On the other hand, the total leukocyte count was significantly increased in all diseased groups. In addition, there was a significant difference between diseased cows and buffalo with chronic TRP, in which diseased buffalo showed higher leukocytes more than in diseased cows. This increase could be attributed to tissue injury and inflammation. This result has coincided with Radostits et al.(2010) who reported that, leukocytosis and erythropenia are the most hematological alterations observed in chronic inflammatory diseases including TRP.

The biochemical analysis revealed that the total protein was significantly increased in chronic TRP diseased cows and buffalo. Despite the total hyperproteinemia, the serum albumin concentration was significantly decreased in these groups as a result of hyperglobulinemia with a subsequent decrease in $\mathrm{A} / \mathrm{G}$ ratio. This result comes in agreement with other studies reported by Hirvonen and Pyorala (1998), Russell 
and Roussel (2007), and Saleh et al. (2008). Hirvonen and Pyorala (1998) indicated that, the common cause of hyperglobulinemia is chronic antigenic stimulation such as chronic inflammatory diseases as TRP. Therefore, globulin concentration has a great value for detecting chronic inflammatory diseases. However, there was a significant decrease in albumin concentration along with simultaneous decrease $A / G$ ratio suggested a selective loss of albumin or sequestration of albumin into third body spaces (Thomas, 2000). Immunoglobulin G (IgG) concentration was significantly increased in chronic TRP diseased cows and TP diseased buffalo, but its level was significantly reduced in acute TRP diseased buffalo in comparison to control group. This alteration in IgG concentration came along with changes in globulin concentration in the same groups. Because IgG is a part of chronic phase protein (gamma globulin) which increase in the relation to the presence of chronic inflammation and products of tissue injury and these changes result from the release of inflammatory intermediates (Hosseini et al., 2015). In contrast, the concentration of haptoglobin was significantly increased in acute TRP diseased buffalo and highly significantly increased in TP diseased cow and buffalo as it is one of acute phase proteins which increase when the disease developed and decrease in the recovery stage (Smith et al., 1998). However, its level remained high in chronic TRP diseased cows and this indicated that the stimulation was continuous as reported by Bozukluhan and Gokce (2007). Cardiac troponin concentration was highly significantly increased in both TP groups as cardiac troponin used as a highly specific marker of myocardial damage as reported by Vasatova et al.(2013). 
Finally, it can be concluded that erythropenia, anemia, and leukocytosis are the most significant hematological changes in acute and chronic TRP in both cattle and buffalo. Also, hyperproteinemia, hyperglobulinemia, and hypoalbuminemia are the significant biochemical changes used for differentiating between chronic and acute TRP. Additionally, globulin and IgG have considered also a good biomarker for differentiating acute TRP from chronic ones. Haptoglobin is considered a good indicator reflect the intensity of inflammatory response and progression of the disease. In addition, there is no significant difference between cattle and buffalo in response to foreign body syndrome.

Table (1): Hematological values for control groups in comparison to different groups of TRP in buffalo and cows

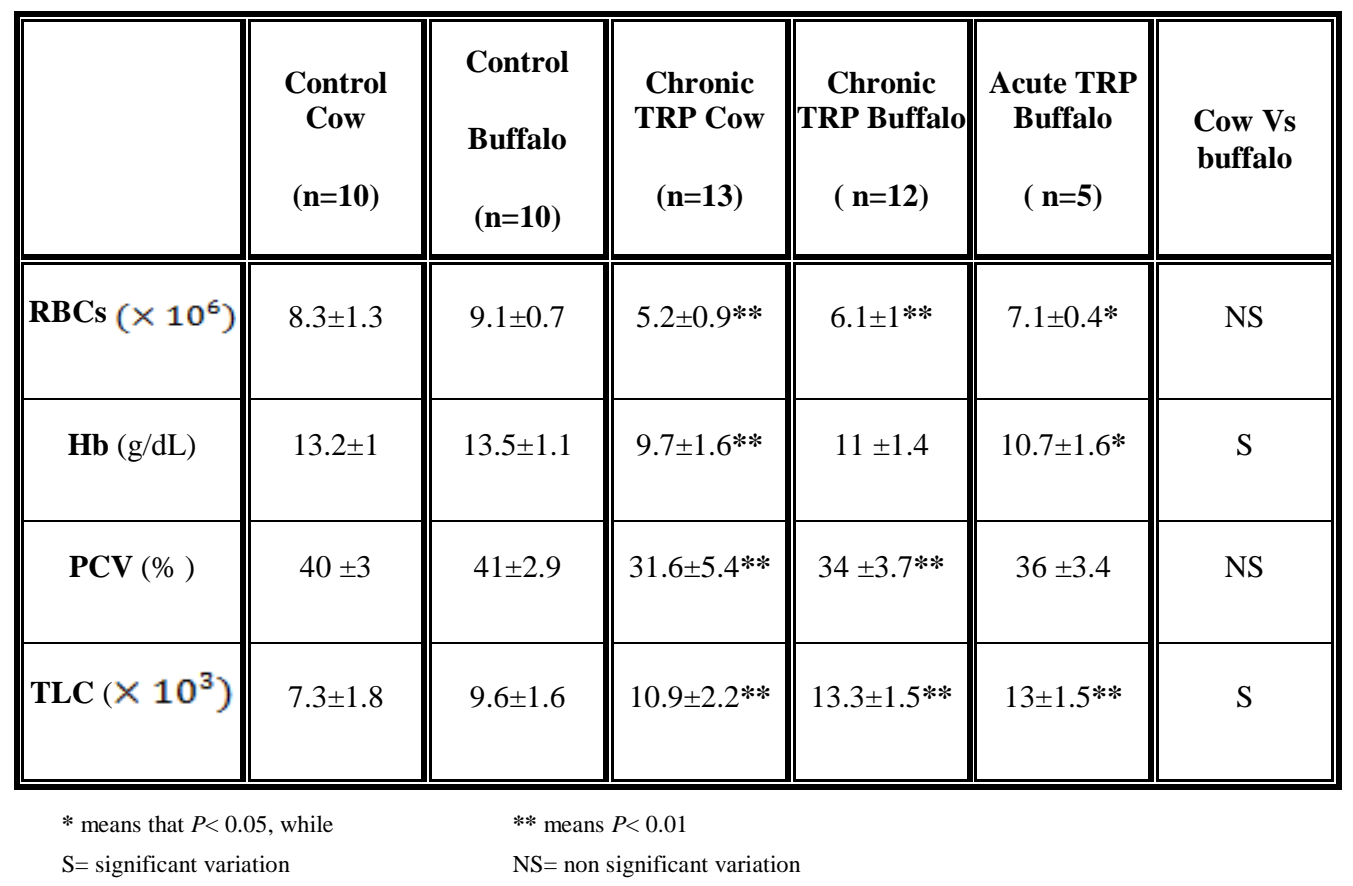

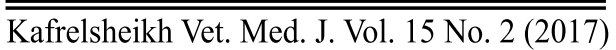


Shimaa Fawzy et., al.

Table (2): Hematological values for control groups in comparison to TP in buffalo and cows

\begin{tabular}{|c||c||c||c||c||c||}
\hline & $\begin{array}{c}\text { Control Cow } \\
(\mathbf{n = 1 0})\end{array}$ & $\begin{array}{c}\text { Control Buffalo } \\
(\mathbf{n = 1 0})\end{array}$ & $\begin{array}{c}\text { TP Cow } \\
(\mathbf{n = 5})\end{array}$ & $\begin{array}{c}\text { TP Buffalo } \\
(\mathbf{n = 5})\end{array}$ & $\begin{array}{c}\text { Cow Vs } \\
\text { buffalo }\end{array}$ \\
\hline \hline $\mathbf{R B C s}\left(\mathbf{\times} \mathbf{1 0}^{\mathbf{6}}\right)$ & $8.3 \pm 1.3$ & $9.1 \pm 0.7$ & $5.5 \pm 1 *$ & $4.9 \pm 1.1 * *$ & NS \\
\hline $\mathbf{H b}(\mathbf{m g} / \mathbf{d L})$ & $13.2 \pm 1$ & $13.5 \pm 1.1$ & $10.8 \pm 2.5$ & $10.9 \pm 1.5 *$ & NS \\
\hline $\mathbf{P C V}(\mathbf{\%})$ & $40 \pm 3$ & $41 \pm 2.9$ & $34 \pm 4.5$ & $36.4 \pm 2.3 *$ & NS \\
\hline $\mathbf{T L C}(\times \mathbf{1 0})$ & $7.3 \pm 1.8$ & $9.6 \pm 1.6$ & $11.6 \pm 1.8 *$ & $11.5 \pm 1.2$ & NS \\
\hline \hline
\end{tabular}

* means that $P<0.05$, while

** means $P<0.01$

$\mathrm{S}=$ significant variation

$\mathrm{NS}=$ non significant variation

Table (3): Blood serum biochemical analysis in control groups in comparison to different groups of TRP in buffalo and cows

\begin{tabular}{|c|c|c|c|c|c|c|}
\hline & $\begin{array}{l}\text { Control } \\
\text { cow } \\
(n=10)\end{array}$ & $\begin{array}{c}\text { Control buffalo } \\
(\mathrm{n}=10)\end{array}$ & $\begin{array}{c}\text { Chronic TRP } \\
\text { diseased } \\
\operatorname{Cow}(n=13)\end{array}$ & $\begin{array}{c}\text { Chronic TRP } \\
\text { diseased buffalo } \\
(n=12)\end{array}$ & \begin{tabular}{|c} 
Acute TRP \\
diseased buffalo \\
$(\mathrm{n}=5)$
\end{tabular} & $\begin{array}{l}\text { Cow Vs } \\
\text { buffalo }\end{array}$ \\
\hline Total protein $(g \%)$ & $6.9 \pm 0.2$ & $7.1 \pm 0.3$ & $7.3 \pm 0.5^{*}$ & $7.5 \pm 0.6^{*}$ & $6.8 \pm 0.3$ & NS \\
\hline $\operatorname{Albumin}(\mathrm{g} \%)$ & $3.7 \pm 0.3$ & $3.9 \pm 0.2$ & $2.8 \pm 0.9^{* *}$ & $2.6 \pm 0.7 * *$ & $3.9 \pm 0.2$ & NS \\
\hline Globulin(g\%) & $3.1 \pm 0.2$ & $3.2 \pm 0.2$ & $4.50 \pm 1 * *$ & $4.9 \pm 1 * *$ & $2.9 \pm 0.5$ & NS \\
\hline A/G ratio & $1.2 \pm 0.2$ & $1.2 \pm 0.1$ & $0.70 \pm 0.40^{* *}$ & $0.6 \pm 0.2^{* *}$ & $1.4 \pm 0.3$ & NS \\
\hline Haptoglobin(g/l) & $0.02 \pm 0.1$ & $0.03 \pm 0.02$ & $0.07 \pm 0.06^{*}$ & $0.07 \pm 0.06$ & $0.5 \pm 0.3^{*}$ & NS \\
\hline IgG (mg/dl) & $0.7 \pm 0.3$ & $1.2 \pm 0.5$ & $1.3 \pm 0.6^{*}$ & $1.6 \pm 0.5$ & $0.4 \pm 0.3 * *$ & NS \\
\hline$*$ means that $\mathrm{P}<0$. & while & & $P<0.01$ & & & \\
\hline $\mathrm{S}=$ significant vari & & $\mathrm{NS}=$ & ignificant vari & & & \\
\hline
\end{tabular}

$\overline{\text { Kafrelsheikh Vet. Med. J. Vol. } 15 \text { No. } 2 \text { (2017) }}$ 
Comparative Study On Traumatic Reticuloperitonitis ...

Table (4): Blood serum biochemical analysis in control groups in comparison to different groups of TP in buffalo and cows

\begin{tabular}{|c||c||c||c||c||c|}
\hline & $\begin{array}{c}\text { Control cow } \\
(\mathbf{n}=\mathbf{1 0})\end{array}$ & $\begin{array}{c}\text { Control } \\
\text { buffalo(n=10) }\end{array}$ & $\begin{array}{c}\text { TP diseased } \\
\text { cow(n=5) }\end{array}$ & $\begin{array}{c}\text { TP diseased } \\
\text { buffalo(n=5) }\end{array}$ & $\begin{array}{c}\text { Cow Vs } \\
\text { buffalo }\end{array}$ \\
\hline \hline Total protein (g\%) & $6.9 \pm 0.2$ & $7.1 \pm 0.3$ & $6.4 \pm 0.6$ & $7 \pm 0.1$ & $\mathrm{NS}$ \\
\hline Albumin (g\%) & $3.7 \pm 0.3$ & $3.9 \pm 0.2$ & $2.8 \pm 0.6^{* *}$ & $3.4 \pm 0.5$ & $\mathrm{NS}$ \\
\hline Globulin (g\%) & $3.1 \pm 0.2$ & $3.2 \pm 0.2$ & $4.3 \pm 0.7 *$ & $3.7 \pm 0.5$ & $\mathrm{NS}$ \\
\hline A/G ratio & $1.2 \pm 0.2$ & $1.2 \pm 0.1$ & $0.7 \pm 0.3 * *$ & $1 \pm 0.3$ & $\mathrm{~S}$ \\
\hline Haptoglobin $(\mathbf{g} / \mathbf{l})$ & $0.02 \pm 0.01$ & $0.03 \pm 0.02$ & $0.2 \pm 0.06 * *$ & $0.05 \pm 0.03 * *$ & $\mathrm{NS}$ \\
\hline IgG (mg/dl) & $0.7 \pm 0.3$ & $1.2 \pm 0.5$ & $1.2 \pm 1.2$ & $1.6 \pm 0.4 *$ & $\mathrm{NS}$ \\
\hline Cardiac troponin $(\boldsymbol{\mu g} / \mathbf{m l})$ & $0.03 \pm 0.02$ & $0.004 \pm .003$ & $0.2 \pm 0.008^{* *}$ & $0.02 \pm 0.007 * *$ & $\mathrm{NS}$ \\
\hline
\end{tabular}

* means that $P<0.05$, while

** means $P<0.01$

$\mathrm{S}=$ significant variation

$\mathrm{NS}=$ non significant variation

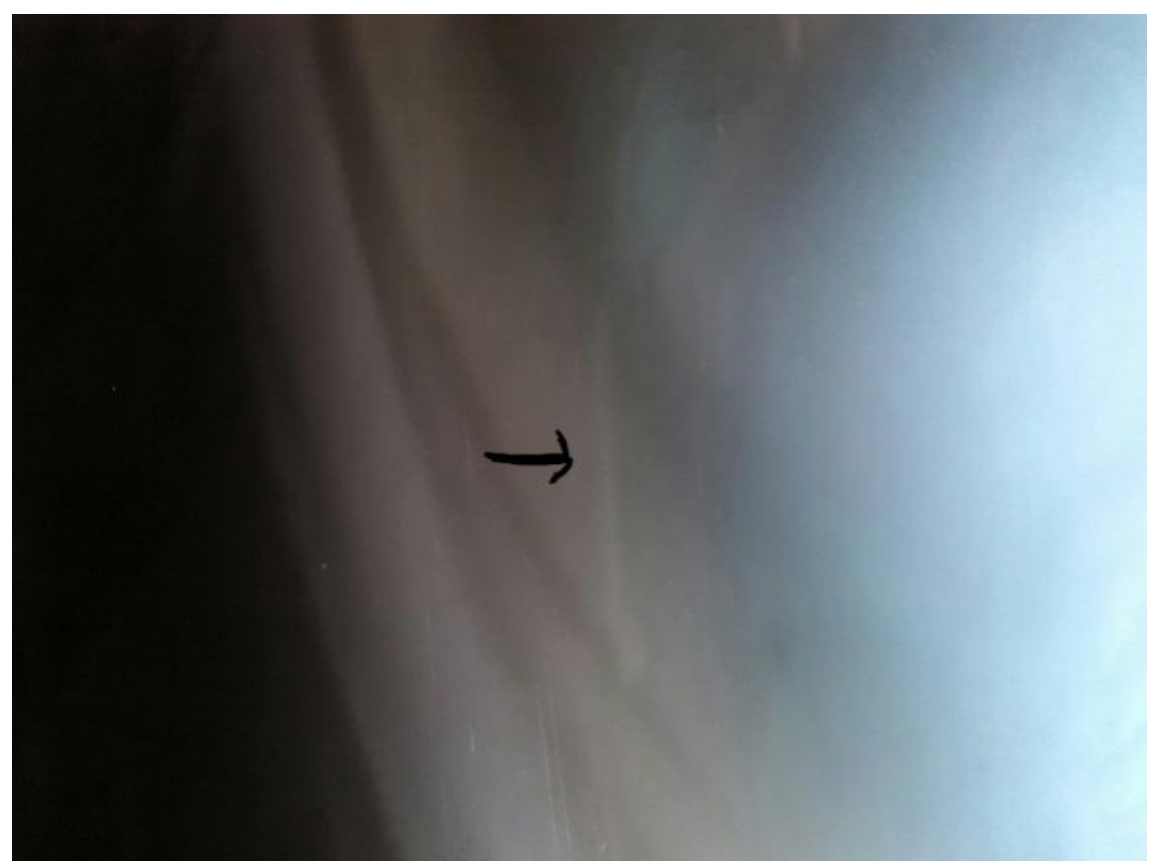

Fig. (1): Lateral radiograph of the caudal thorax and cranial abdomen showing a metallic pin in the reticulum of buffalo

$\overline{\text { Kafrelsheikh Vet. Med. J. Vol. } 15 \text { No. } 2 \text { (2017) }}$ 


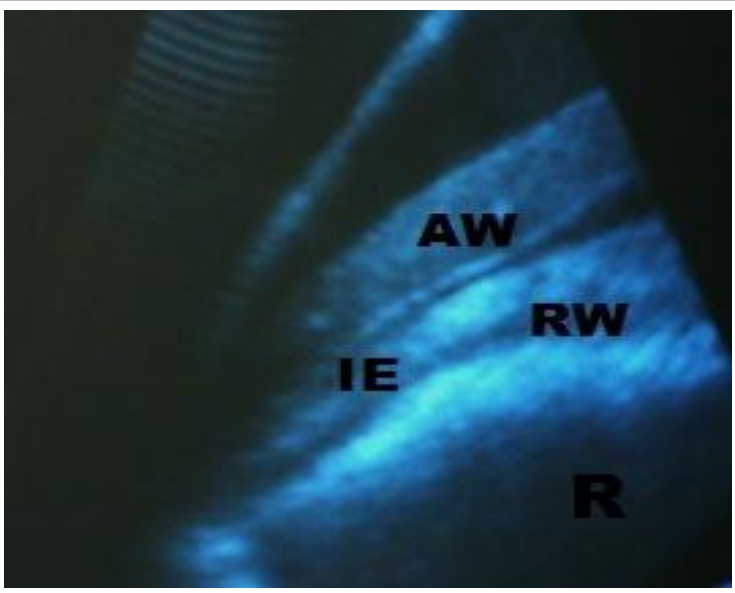

Fig. (2): Ultrasonographic image of buffalo with acute traumatic reticuloperitonitis. Reticular contour corrugated with an increase in its thickness due to inflammatory changes. AW: Abdominal wall; IE: Inflammatory exudate; RW: Reticular wall; R: reticulum.

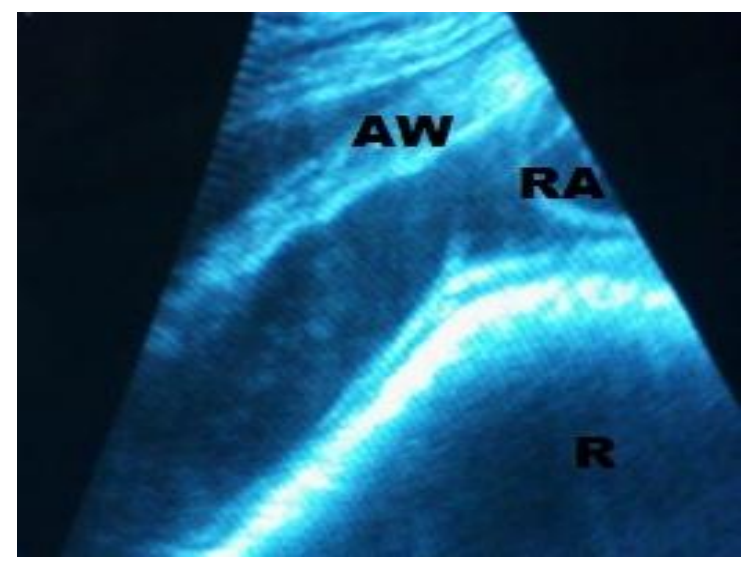

Fig. (3): Ultrasonographic image in cow with chronic traumatic reticuloperitonitis. It is showing an abscess in the reticular wall which appears as a circumscribed structure containing hypoechoic fluid while there was a deposit of fibrin interbreeds with fluid pockets between reticulum and dorsal ruminal sac, deposits of fibrin with various echogenicities. AW: Abdominal wall; RA: Reticular abscess; R: reticulum 


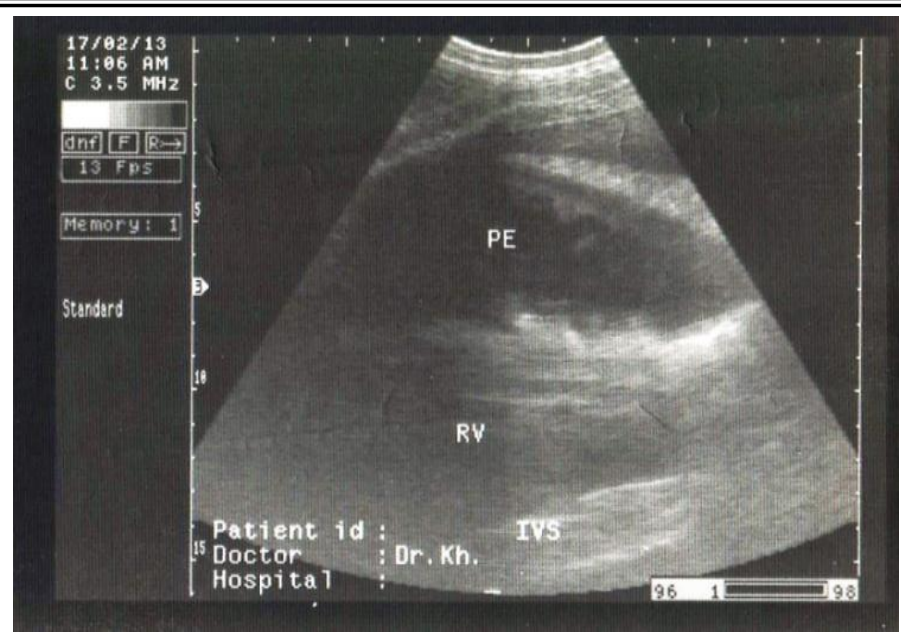

Fig. (4): Ultrasonographic image in buffalo with TP that revealed thick pericardium, pericardial effusion, the effusion contains fibrin shreds. PE: Pericardial effusion; RV: Right ventricle; IVS: Interventricular septum.

\section{REFERENCES}

- Abdelaal A, Floeck M, El Maghawry S and Baumgartner W (2009): Clinical and ultrasonographic differences between cattle and buffalo with various sequelae of traumatic reticuloperitonitis. Veterinarni Medicina, 9: 399-406.

- Bartholomew RJ and Delaney AM (1966): Proceedings of the Australian Association of clinical Biochemists, 1: 214.

- Bozukluhan K and Gokce HI (2007):Investigation of some acute phase proteins in cattle with traumatic reticuloperitonitis or with traumatic pericarditis. J Fac Vet Med Erciyes Univ, 4: 107-113.

- Braun U, Götz M and Marmier O (1993):Ultrasonographic findings in cows with traumatic reticuloperitonitis. Vet. Rec, 133: 416-422. 
- Braun U and Goetz M (1994): Ultrasonography of the reticulum in cows. Am. J. Vet. Res, 55: 325-332.

- Braun U, Fluckiger M and Gotez M (1994): Comparison of ultrasonographic and radiographic findings in cows with traumatic reticuloperitonitis. Veterinary Record, 135: 470-78.

- Braun U (2009): Ultrasonography of the gastrointestinal tract in cattle. Veterinary Clinics of North America: Food Animal Practice, 25: 567-590.

- Cannon DC (1974): In clinical chemistry principals and Techniques, $2^{\text {nd }}$ Ed. R. J. Henry et al.: Eds. Harper \& Row, Hagerstown, M. D,11: 411-421.

- Dodia VD, Kelawala NH, Suthar DN and Prajwalita Sutaria (2014):

- Haematological and Serum Biochemical Profile of Cattle Affected with Plastic Foreign Bodies. Intl. J. Scient. Res. Publ, 4 (8) : 1-2.

- Dubensky RA and White ME (1983): The sensitivity, specificity and predictive value of total plasma protein in the diagnosis of traumatic reticuloperitonitis. Canadian Journal of Comparative Medicine, 7: 241-44.

- Ghanem MM (2010): Comparative study on traumatic reticuloperitonitis and traumatic pericarditis in Egyptian cattle. Turk J Vet, 34(2): 143- 153.

- Gunes V, Atalan G, Citil M and Erdogan HM (2008): Use of cardiac troponin kits for the qualitative determination of myocardial cell damage due to traumatic reticuloperitonitis in cattle. Vet Rec, 19;162(16):514-7. 
- Hirvonen J and Pyorala S (1998): Acute-phase response in dairy cows with surgically-treated abdominal disorders. The Veterinary Journal, 155: 53-61.

- Hosseini A, Namazi F, Oryan A and Nazifi S (2015): Correlation between some hematological parameters, acute phase proteins and serum immune globulins in experimental caprine besnoitiosis. Journal of Parasitic Diseases: Official Organ of the Indian Society for Parasitology,39(2): 155-161.

- Jafarzadeh SR, Nowrouzian I, Khaki Z, Ghamsar SM and Adibhashemi F (2004): The sensitivities and specificities of total plasma protein and plasma fibrinogen for the diagnosis of traumatic reticuloperitonitis in cattle. Preventive veterinary medicine, 65(1): 1-7.

- Khalphallah A, Abu-Seida MA, Abdelhakiem M, ELmeligy E and Mohamoud TU (2016): Laboratory, radiographic and ultrasonographic findings of acute traumatic reticuloperitonitis in buffaloes. Asian J. Anim. Vet. Adv, 11(11):675-683.

- Kumar $V$ and Dhar $P$ (2013): Foreign body impaction in a captive Sambar (Rusa unicolor), Vet. World, 6 (1) : 49-50.

- Misk NA and Semieka MA (2001):The radiographic appearance of reticular diaphragmatic herniation and traumatic pericarditis in buffaloes and cattle. Vet Radiol, Ultras, 42: 426-430.

- Radostits, OM, Gay CG, Blood, DC, and Hinchcliff KW (2010): Veterinary Medicine, A textbook of the Diseases of Cattle, Sheep, Pigs and Goats. WB Saunders Company Ltd. 
- Rosenberger G, Dirksen G, Grunder HD, Grunert E and Krause D (1979):Digestive system In: Clinical Examination of Cattle, 2nd ed. G.Rosenberger et al.(Eds)Paul Parey, Hamburg,Germany,3: 218-220.

- Roussel AJ, Whitney MS and Cole D (1997):Interpreting a bovine serum chemistry profile: Part: 1. Vet. Med, 92: 551-558.

- Russell KE and Roussel AJ (2007):Evaluation of the ruminant serum chemistry profile. Veterinary Clinics of North America: Food Animal Practice, 23(3): 403-426.

- Saleh MA, Rateb HZ and Misk NA (2008):Comparison of blood serum proteins in water buffaloes with traumatic reticuloperitonitis and sequelae. Research in Veterinary Science, 85: 208-213.

- Shan G, Huang W, Gee SJ, Buchholz BA, Vogel, JS and Hammock $B D$ (2000): Isotope-labeled immunoassays without radiation waste. Proceedings of the National Academy of Sciences, 97(6): 2445-2449.

- Smith BI, Donovan GA, Risco C, Young C and Stanker LH (1998): Serum haptoglobin concentrations in Holstein dairy cattle with toxic puerperal metritis. Vet. Rec, 142: 83-85.178.

- Thomas JS (2000): Overview of plasma proteins, In: Schalm's Veterinary Hematology, B.F. Feldman, J.G. Zinkl, \& N.C. Jain, (Eds.), Lippincott Williams, Wilkins, Philadelphia, USA,8: 891-898

- Vanitha V, Nambi AP, Gowri B and Kavitha S (2010): Rumen impaction cattle with indigestible foreign bodies Tamil Nadu S. Veterinary and Animal Science, 6: 138-140.

- Vasatova, M, Pudil R, Horacek JM and Buchler T (2013): Current applications of cardiac troponin $\mathrm{T}$ for the diagnosis of myocardial damage. Adv. Clin. Chem, 61: 33-65. 
دراسة إكلينيكيه مقارنة على التهاب الثبكية الصفاقي والتهاب التامور الرضحي في الأبقار

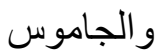

\section{شيماء فوزي 1، نجلاء جمعة²، مدحت ناصف² ، أحمد مجدي حافظ²}

مديرية الطب البيطري، محافظة كفر الثيخ 1

قسم طب الحيوان، كلية الطب البيطري، جامعة كفر الثيخ2

قـ أجريت هـذه الدراسـة لإجـراء مقارنــة بـين التغيـرات الاكلينيكوبانولوجيـهـ والتصويرالثـعاعي

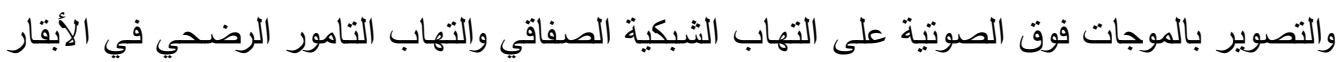

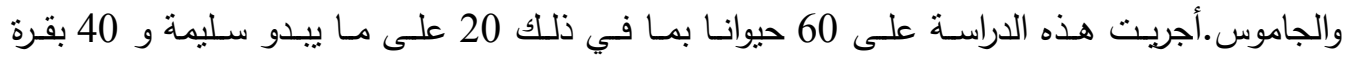

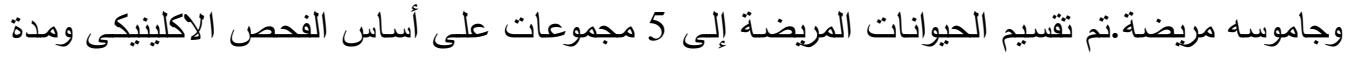

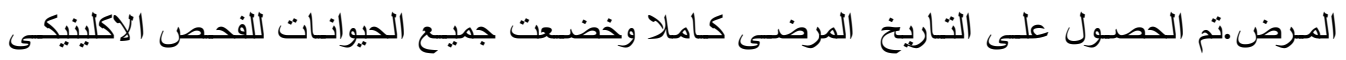

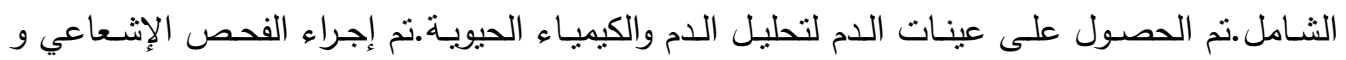
بالموجات فوق الصوتية على منطقة الثبكية ومنطقة القلب. كثفت نتائج الموجات فوق الصوتية على

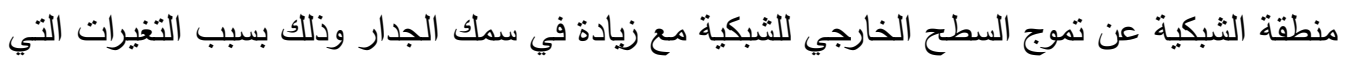

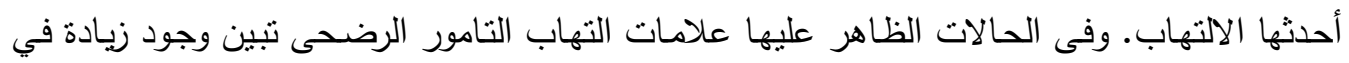
سمك جدار التامور و إرتشاح في أغشية القلب مع وجود خيوط من الفيبرين. أظهرت تحليل الدم انخفاضـا في تركيز كرات الدم الحمراء، تركيز الهيموجلوبين مع زيادة عدد

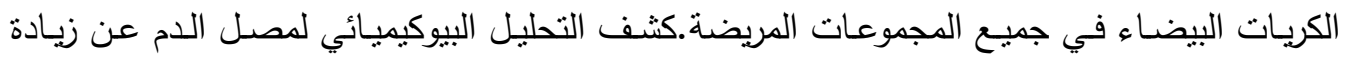

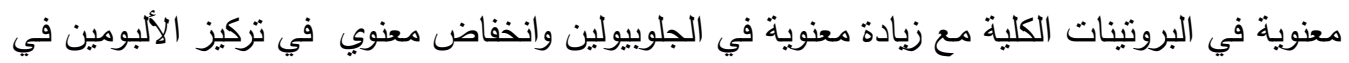

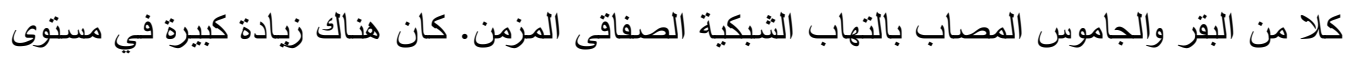
هابتوجلوبولين في التهاب الثبكية الصفاقى الحادة في الماثشية والجاموس بينما البروتين المناعي كان

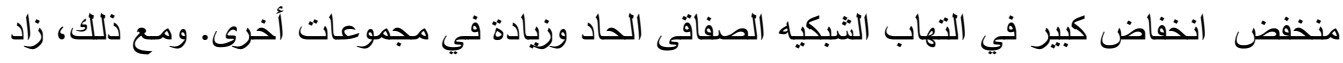

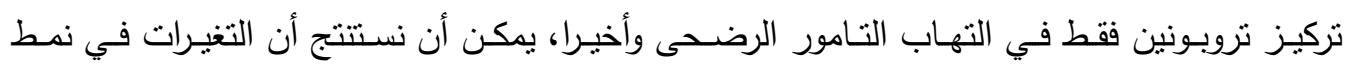

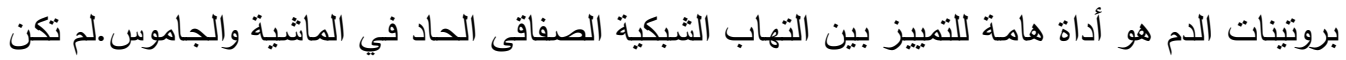
هناك تغيرات بيوكيميائية كبيرة بين الماشية والجاموس كاستجابة لمتلازمة الجسم الغريب. 